\title{
INTRODUCING ACEH TRADITIONAL CULINARY AS TOURIST ATTRACTIONS
}

\author{
Dewi Turgarini, Fitri Abdillah. Universitas Pendidikan Indonesia, Sekolah Tinggi \\ Pariwisata Bali Internasional \\ dewiturgarini@gmail.com, fitri_adie@yahoo.com
}

\begin{abstract}
In recent time, tourism industry has not only been one of the rapidly growing fields of the world economy, but also has brought about economy development for diverse states and regions. Food is one of the principal factors are items that have been neglected in the most of the studies. To survive, in the first place, every tourist as an organism need to eat and drink and the uniqueness of culinary make it more interest them. We choose Aceh because it is one of the provinces in Indonesia which has a long cultural history, including the potential culinary.

This study was designed to find local culinary deserve to be featured as an identifier of Aceh as a culinary destination. The approach used in this study is a descriptive exploratory study, because this study is a description of the data in tabular form and narrative facts corresponding field. The primary data obtained from interviews, observations and focus groups involving all tourism stakeholders.

The results obtained showed that Aceh has a varied culinary potential and very full featured, yet necessary efforts to familiarization some of food Aceh in the international community. Another thing is that most typical culinary Aceh is presented for ceremonial purposes that have not been commercialized. The people of Aceh Aceh saw three meals that can be used as icon is Kuwah Belanggong, Ayam Tangkap, and Mie Aceh. The promotions and strategies to educate travelers about the culinary profile seem to be done to make the maximum of the featured foods familiar to tourists.
\end{abstract}

Keywords: local cuisine, familiarization and education

\section{INTRODUCTION}

\section{Background}

Tourism has developed into industries which is capable of moving the world economy. This is caused by the opening of various tourism destinations in the world that led to the increase in job creation, infrastructure development and economic gains as a result of international trade (UNWTO, 2013).

In recent years, the food has gained recognition from the government, business, and academia as an integral part of the tourism product. An understanding of the food was also shifted from simply a product differentiator for tourism destinations (distinctive competitiveness). Local food is an important 
element that can help to create new experiences for tourists and increase the attractiveness of the destination. Local products will add a unique travel experience, and provide motivation for visitors to come to the site. Travelers may even be tempted to stay longer in one place due to the availability of food products, and related activities. Tourism became an additional sales outlet for producers of food that stimulate and revitalize the local economy. The food in the end is an important consideration in the development initiatives to strengthen tourism destination, and to create linkages between industry benefit food production and tourism industry.

Wurianto (2008) states that traditional cuisine is a cultural richness that should be explored as a cultural asset. This needs to be done to offset the invasion of foreign culinary, and culinary franchise models as the impact of free markets and globalization. There is a link between the sourcing of food ingredients, cultures, traditions, customs and public order. Therefore tradisional food for the community in addition to a source of food and medicine, as well as means of implementation of the customs, traditions and belief systems. Culinary may also be viewed as an economic capital, because the tourism base could increase foreign exchange

Currently there is a demand in the food tourism is becoming an important sector of the tourism industry. However, the popularity of food tourism has been recognized for decades. In Australia and Canada, culinary generate $\$ 1$ billion per year, and is an important part of the development of remarkable destinations. In addition, more countries are beginning to realize the development potential of culinary tourism to boost economic kinerje. Singapore, for example, the government developed the "New Asia-Singapore Cuisine" in order to attract tourists to enjoy the cuisine that is the theme of the incorporation of this type of cuisine western and eastern cuisine. Singapore is working hard to develop the image of the food and wine, so it is known as the main destinations in Asia and the World.

Consumption of food turned out to be an integral aspect of the experience traveled, not just a matter of taste and presentation, but also by a sense of enjoying the place. It can almost be said of all to eat. Local food is a fundamental component of the destination attributes, add rich attractions and the overall travel experience (Symons, 1999). This is what makes food become an important constituent of the production and consumption of tourism. When you see the following

a) Journey in which there is an appreciation and consumed local or regional food.

b) Travel with the main purpose of enjoying food, and drinks as a travel experience or to attend a specific culinary activities such as cooking schools, visit the places of production of food or drink, folk market, or enjoy the food at various places that provide them (taste trail).

c) The unique experience of eating and drinking

Thus it is clear that culinary tourism is not only a category in tourism but also an opportunity for destinations, and the industry to gain competitive side (ICTA 2009). Surely culinary tourism can improve its competitiveness, must be supported by the resources can be immortal, and difficult to be imitated and replaced.

Culinary tours are likely to expand the domestic tourism activities, with consumers traveling to places to eat, and drink (usually local). A domestic survey 
in America found that $17 \%$ are involved in activities related to culinary tourism. International Association of Culinary Tourism predicts that this type of travel will grow rapidly in the coming years. According to USA Today (2007), 27 million Americans have made culinary activities as part of their trip in the past three years. In the UK, culinary estimated to be worth nearly $\$ 8$ billion per year.

International culinary significantly less developed than domestic culinary. This happens because determining what foods are selected when traveled, usually not a major concern. The growth in popularity of ethnic cuisine such as Thailand, India, and China due to significant growth in tourism where visitors can sample local food, and gain experience with it. Culinary festival is the only instance in which the decision to travel was taken solely on the basis of the gastronomic experience offered. Currently there are not more than one million international culinary travelers traveling every year.

Culinary tourism has grown into a market segment, and usually a gastronomic tour is often combined with other activities such as cultural tourism, cycling, walking. As a result, this segment demand by consumers with a wide circle. This then led to the emergence of local food and drink festival, as well as an increased interest in the local market. The growth of this niche market will be strong in the next 5-10 years, albeit from a relatively small base, so that the There are many many regions, and cities in Indonesia which has potential as a culinary destination area that can be developed but has not been well managed, and integrated with, so it can not be recognized and visited by the public. The condition is understood that the need for the development of integrated culinary tourism potential between managers, government and society. The roots of these efforts is the urgency to do promotions in introducing culinary tourism destinations located in Indonesia on the local population, domestic, and foreign tourists.

In particular, this study aims to determine the level of development of the quality of life in Aceh tourism destination. Some questions about the development of tourism destinations is how to change the quality of life occurred in the region and indeed true that the development of tourism destinations have an impact on changes in quality of life in society. In other words, besides tourism destination development phase is determined by the number of tourists visiting also by the level of quality of life in society. This study wanted to see if increased number of tourists that caused the passing of economic activity has also resulted positive to the level of the quality of life of local communities in development.

\section{REFERENCE REVIEW \\ Tourism and Food}

The linkage of food and tourism destination today has developed not only as a product required by tourists biological basis, but has also been used as a distinctive destination by creating an atmosphere that is impressive. It then becomes the identity of the destination. Food can also add value to the core tourism product and became the focus for a special occasion. Besides the food may be used to attract a specific market niche in small quantities but usually have good taste and can afford to pay a large amount. Today many research about food and food tourism focuses more on tourism (tourism food), from the perspective of tourist satisfaction, so often defined by special interest approach. Food was also 
discussed in the context of agro-tourism. Generally Hall and Mitchell define food tourism as:

Visitation to primary and secondary food producers, food festivals, restaurants and specific locations for which food and tasting and/or experiencing the attributes of a specialist food production region are the primary motivating factors for travel (Hall and Mitchell, 2001). From the above definition of Hall and Mitchell does not mean that the experience of eating at a particular restaurant when traveling can be regarded as a food tourism, because it more precisely, food tourism is the desire to enjoy the food, dishes or cooking should be the primary motivation for the visit. In the above definition is made distinctions among tourists who consume the food as part of a sightseeing trip with tourists who visit to an entire area of

In the context of the role of food in tourism, Hall and Mitchell (2001) make up the category based on the motivation and behavior of tourists to enjoy the food and enjoy it.

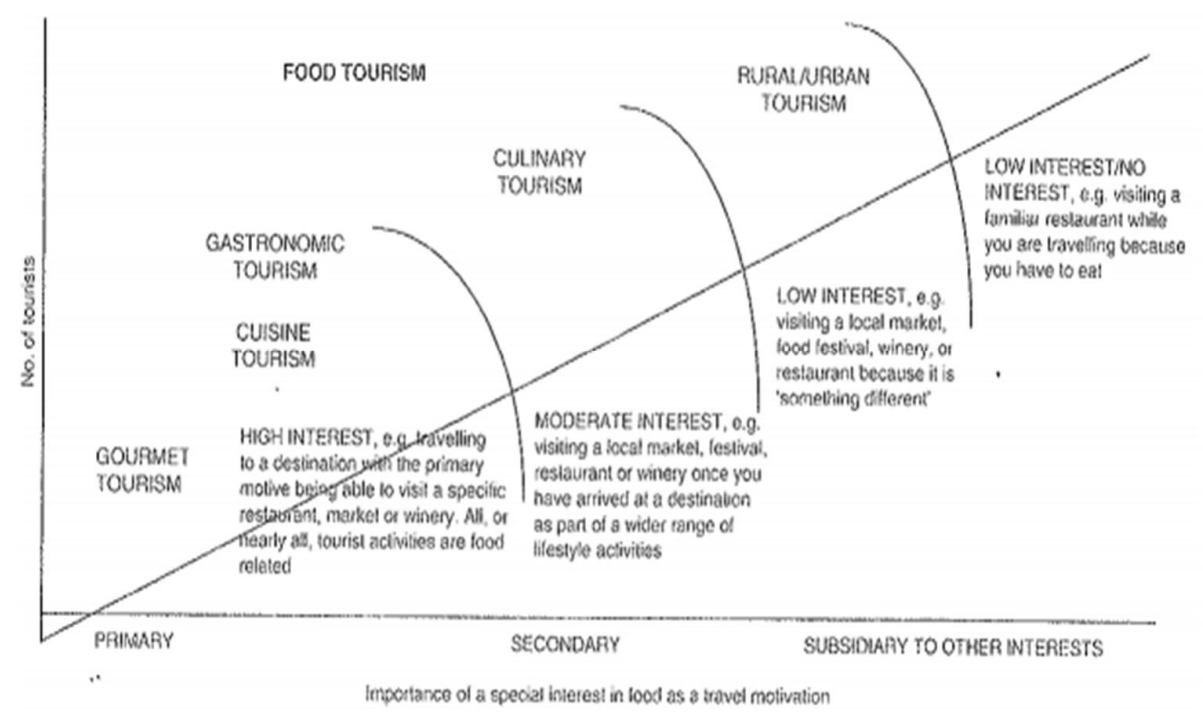

Figure 1. Categorization Food Tourism based Motivation and Number of tourists

From the picture above Hall and Mitchell wanted to convey that food tourism can dikatagori using interest rate and the number of tourists visiting tourists. Traveller interest divided into three categories: primary, secondary, and tertiary. Description The categorization is as follows.

d) Gastronomic Tourism, this kind of tourism is done by tourists with a very high motivation to certain foods or beverages in certain areas. It is usually associated with expensive or the 'top end' restaurants, wineries, and festivals. Almost all tourist activities undertaken related to that interest. Gastronomic tourism is divided widened two which is gourmet tourism ${ }^{l}$ and gastronomic tourism ${ }^{2}$.

1 Gourmet is a cultural ideal associated with the culinary arts of fine food and drink, or haute cuisine, which is characterised by refined, even elaborate preparations and presentations of aesthetically balanced meals of several contrasting, often quite rich courses.

2 Gastronomic tourism is an experience pursued by visiting and tasting food and beverages at primary or secondary producers', visiting food and beverage festivals and consuming authentic specialties in various restaurants. An increasingly popular form of gastronomic tourism is an 
e) Second Subset is culinary tourism, is culinary tours include general foods business as part of a lifestyle like visiting a local festival or market. In this category of food is a secondary motivation for tourists.

f) Third Subset is Urban tourism / rural. It regards tourism type of food as part of the necessities of life. Traveller interest of this type is not the food, but if they feel that can not tasty, they are still paying interest.

Corigliano (2002) states that culinary tourism can be categorized as cultural tourism, because of his relationship with the preservation of agricultural products. Culinary tours to tourists provide a unique experience to enjoy the food, certain cultural and associate it with the history of the past. The linkage between tourism with various other sectors are illustrated by analogy model of wine tourism as follows.

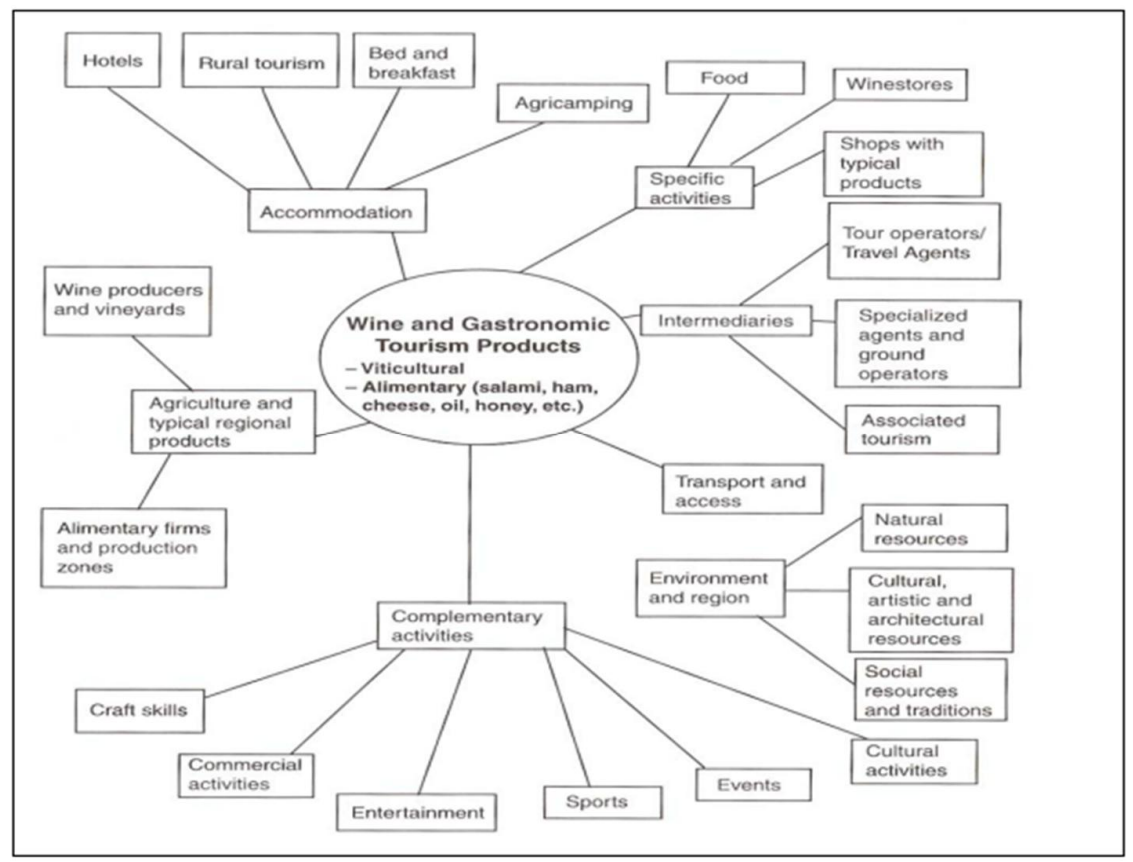

\section{Figure 1 Linkages Wine Tourism Component with Other Tourism Sectors (Supply system) (Corigliano; 2002)}

Instead Wolf (2006) describes the culinary tourism as just "journey to seek and enjoy, prepared food and beverages". Culinary tours can also include, for example, a visit to the market, prepare a special meal at a friend's house, attended a special event at the famous restaurant or eat at local restaurants and so on.

Meanwhile Muhilal (1995) calls the traditional food is food that has been entrenched in Indonesian society, and has been around since tribal ancestors archipelago. The traditional food is food that is concentrated with local traditions. Meanwhile Hadisantosa (1993), defines the traditional foods as foods consumed by specific ethnic groups and regions, prepared by recipes from generation to generation. The materials used are local and the food is produced also in accordance with the tastes of society.

activity of tourists who attend diff erent multi-day schools of authentic regional cooking (Hall \& Mitchell, 2006) 


\section{Tourism Destination}

Tourism destination is one important part of the tourism system. The term refers to the essence of tourism destination of tourism which is often understood as people travel from home to a destination, staying there for a limited time period, and then returned to its original place. The concept of tourism destination is one of the most important, and complex in the discussion of tourism. Inskeep (1991) defines as a tourism destination in targeted geographical location at the time of a person traveling; while Gunn (1994) viewed as a tourism destination area tourist travel market and refers to the travel destination zone is a geographical area that includes the development of the region and the community in order to satisfy tourist travel destinations. Therefore, tourism destinations can be described at different scales ranging from the village level up to the region, city or resort, specialized sites and even an influx of special attractions are visited by tourists. A tourism destination is generally understood as a concept of spatial or geographic visited by visitors from outside the location in order to gain ekonomis.Oleh therefore can not be called as a tourism destination if it is not visited by visitors from outside.

David and Tozser (2009) refers to the concept of Carter and Fabricius (2007) describes a tourism destination as the physical location where tourists spend a minimum of one night the place is. The location has tourism attractions, products and services required by the traveler par during the stay. Tourism destinations have physical limitations and administrative, which is determined by its management, and has the image and perception as an attraction for tourists.

Inskeep (1991), suggests some of the components involved in the development of tourism destinations, namely:

a) Tourist attractions, namely tourist activities in question can be all things related with natural environment, the culture, the uniqueness of an area and other activities related to tourism activities that attract tourists to visit a tourist attraction.

b) Akomodation, namely a wide range of hotels and various types of other facilities associated with the service to the tourists who intend to stay overnight during a sightseeing trip they do.

c) Amenitas, namely the various facilities and tourist services in the planning of tourist areas. The amenities include tour and travel operations (also called reception services). Such facilities eg restaurants and various types of other eating places, shops selling handicrafts, souvenirs, specialty stores, grocery stores, banks, exchange point uangdan care facilities other financial, tourist information office, personal services (such as salon beauty), health care facilities, public safety facilities (including police stations and fire departments), and travel facilities for incoming and outgoing (such as immigration and customs) and so on.

d) Transportation, includes transportation access to and from the tourist areas, internal transport that connects the main attractions of the tourist area and the surrounding region development area, including all types of facilities and services related to land, water, and air.

e) Infrastructure is the provision of clean water, electricity, drainage, sewerage, telecommunications 


\section{Related Definition of Culinary Tourism Destination}

Various definitions put forward as a reference for the preparation of databases culinary tourism destinations are as follows.

g) Culinary Tourism Destinations is an administrative territorial unit (city) that has one or more local culinary attractions

h) Culinary Attractions is the unity of the geographical area in a city that has one or more local culinary tourism product either restaurants or cafes, food courts, a cottage industry that displays the particular culinary theme and relating to the locality of the region.

i) Products Culinary Tourism is one or more restaurants, cafes, food courts, a cottage industry that displays the particular culinary theme and relating to the locality of the region.

j) Tourism food is food-related tourist activities in tourism destinations such as eating at restaurants, buying local food products, and enjoy the unique experience of eating local production in certain regions

k) Gastronomy Tourism / Culinary refers to trips that are designed to enjoy the unique local production of food or drink

\section{Methodology}

This study is a survey research conducted by combining quantitative and qualitative approaches. In achieving its objectives, the descriptive method is used to explain the phenomenon that is found within the study area. Study method is descriptive method to compile a database of culinary tourism destinations are conducted through desk study, field observation, focus group discussions (FGD), and assessed based on professional judgment. To devise a method or way of solving problems in approaching the goals, objectives, and goals of research activities need to consider the principles of research tailored to the characteristics of the convergence phenomenon and the existing problems. The approach used in this study is a descriptive exploratory study. This type of research is chosen, because this study is a description of the data in tabular form and narrated in accordance facts on the ground.

Secondary data is more widely used to explore the possibility of developing local culinary seeded area. The use of the index value is the result of an agreement made at the date of FGD. FGD is a resource practitioners, academics, indigenous stakeholders, tourism agencies, and NGO representatives from counties and cities in the region of Aceh Darussalam.

\section{RESULT AND DISCUSSION \\ Profile of Aceh Darussalam}

Banda Aceh is one of the main cities and became the capital of Aceh province, Indonesia. As the center of government, Banda Aceh became the center of all economic activity, political, social and cultural. Banda Aceh is the oldest Islamic city in Southeast Asia, where the city of Banda Aceh is the capital of the Sultanate of Aceh.

Based on its history as the capital of Banda Aceh Sultanate of Aceh Darussalam standing in the 14th century. Sultanate of Aceh Darussalam built on the ruins of kingdoms Hindu and Buddhist ever before, such as the Ancient 
Kingdom of Indra, Indra Purwa kingdom, the kingdom of Indra Patra, and Kingdom of Indrapura (Indrapuri). Word of tombstones Sultan Shah, one of the sultans who once ruled the Sultanate of Aceh, obtained information that the Sultanate of Aceh capitalized in Kutaraja (Banda Aceh). The emergence of the Sultanate of Aceh Darussalam were capitalized in Banda Aceh can not be separated from the existence of the Islamic Kingdom Lamuri. At the end of the 15 th century, with the establishment of a good relationship with its neighboring kingdom, the center moved to the throne of the Kingdom Lamuri moved to Meukuta Alam, and Meukuta Alam palace located in the region of Banda Aceh.

Sultan Ali Shah Mughayat ruled the Sultanate of Aceh Darussalam that is capitalized in Banda Aceh, only for 10 years. According to inscriptions found on gravestones Mughayat Sultan Ali Shah, first leader of Sultanate Aceh Darussalam have died in 12 Dzulhijah 936 Hijri Year coincides with the date August 7, 1530 AD. Although the reign of Shah Sultan Mughayat relatively short, but he managed to build Banda Aceh as a center of Islamic civilization in Southeast Asia. At this time, Banda Aceh has evolved into one of the town center of defense who participate in securing maritime trade lanes and traffic of pilgrims from piracy conducted Portuguese fleet.

At the time of Sultan Iskandar Muda, Banda Aceh grow again as a center of maritime trade, especially for commodity pepper when it is very high demand from Europe. Iskandar Muda Banda Aceh as a garden makes the world, starting from the palace complex. Aceh Sultanate palace complex is also named Darud Dunya (World Wildlife).

During the second Dutch aggression, happened a massive evacuation Aceh troops out of Banda Aceh which was then celebrated by Van Swieten by proclaiming the fall of the sultanate of Aceh and rename Banda Aceh became Kuta Raja. Once entered in the lap of the new Indonesian Government since December 28, 1962 the city's name was changed to Banda Aceh returned based on the Ministry of Public Administration and Local Autonomy dated May 9, 1963 No. Des 52/1 / 4343

On December 26, 2004, the city was hit by the tsunami tidal wave caused by an earthquake of 9.2 on the Richter scale in the Indonesian Ocean. This disaster claimed hundreds of thousands of inhabitants and destroyed more than $60 \%$ of the city's buildings. According to statistics issued by the Government of Banda Aceh, the population of Banda Aceh by the end of May 2012 amounted to 248.727 inhabitants.

Location of astronomical Banda Aceh is $05^{\circ} 16^{\prime} 15^{\prime \prime}-05^{\circ} 36^{\prime} 16^{\prime \prime}$ north latitude and $95^{\circ} 16^{\prime} 15^{\prime \prime}-95^{\circ} 22^{\prime} 35^{\prime \prime}$ East Longitude with an average height of 0.80 meters above sea level. Banda Aceh city bounded by the Strait of Malacca to the north; Aceh Besar district in the east and south; danSamudera Indies in the west. In administrartif Banda Aceh consists of 9 districts, 17 Mukim, 70 villages and 20 urban villages. The mayor of Banda Aceh now is Illiza Sa'aduddin Djamal. [4] He was appointed mayor in 2014 through Decree No. 131.11 - 16442014.

Originally there were only four districts in the city of Banda Aceh is Meuraxa Baiturrahman, Kuta Alam and Syiah Kuala. Banda Aceh later developed into nine new districts, namely; 1) Baiturrahman, 2) Banda Raya, 3) Jaya Baru, 4) Kuta Alam, 5) Kuta Raja, 6) Lueng Bata, 7) Meuraxa 8) Syiah Kuala, 9) Ulee Kareng. 


\section{Culinary Potential of Banda Aceh}

As the capital city of the Sultanate of Aceh Darussalam which formerly was one of the five largest Islamic kingdom in the world storing various heritage sites of different ages, ranging from the Sultanate, the Dutch colonial period, time frame joined the Homeland, a time of conflict until the tsunami. Various attraction sites among others are Masjid Raya Baiturrahman, Taman Ghairah Complex, Historical Museum Aceh Tsunami Museum, Tomb of Sultan Iskandar Muda and various other heritage sites located in various corners of the oldest Islamic cities in Southeast Asia.

Based on the inventory conducted by Dewi Turgarini of survey and literature it is known that in 2016 Banda Aceh has a wealth of unique culinary Aceh totaling 53 menu from various menu such as maincourse, complete menu, side dish or vegetable menu, sauce, dessert, snack and beverages as follows;

Table 0.1 Menu of Banda Aceh City

\begin{tabular}{|c|c|c|c|c|}
\hline Type of Menu & \multicolumn{4}{|c|}{ The Name of The Menu } \\
\hline Main Course & \multicolumn{2}{|c|}{$\begin{array}{l}\text { Ayam Tangkap, } \\
\text { Bu Sie Itek, } \\
\text { Dalica, } \\
\text { Dendeng Aceh, } \\
\text { Gulai Kambing, } \\
\text { Kari Kambing (Goat Curry), } \\
\text { Keumamah, }\end{array}$} & \multicolumn{2}{|c|}{$\begin{array}{l}\text { Kuwah Beulangong, } \\
\text { Kuwah Engkot Yee, } \\
\text { Kuwah Itek, } \\
\text { Kuwah Pliek U, } \\
\text { Masam Keueung, } \\
\text { Sie Reuboh Puteh, } \\
\text { Sop Sumsum (Marrow). }\end{array}$} \\
\hline Complete Menu & \multicolumn{4}{|l|}{$\begin{array}{l}\text { Bu Ie Peudah, } \\
\text { Kanji Rumbi, } \\
\text { Mie Aceh, } \\
\text { Mie Caluk, } \\
\text { Nasi Guri. }\end{array}$} \\
\hline $\begin{array}{l}\text { Vegetable / Side } \\
\text { Dishes }\end{array}$ & \multicolumn{4}{|l|}{$\begin{array}{l}\text { Gule Engkot Paya, } \\
\text { Gule Rampoe, } \\
\text { Gule Plik U }\end{array}$} \\
\hline Sauce & \multicolumn{4}{|l|}{$\begin{array}{l}\text { Sambai Peugaga, } \\
\text { Sambai Uedeung. }\end{array}$} \\
\hline Dessert & $\begin{array}{l}\text { Apam Ijo, } \\
\text { Apam Pidie, } \\
\text { Bhoi, } \\
\text { Boh Rom Rom, } \\
\text { Boh Puniaram, } \\
\text { Boh Usen, } \\
\text { Bulukuat, } \\
\end{array}$ & \multicolumn{2}{|c|}{$\begin{array}{l}\text { Kuwah Tuhe, } \\
\text { Chingkui, } \\
\text { Ketan Ikuah Santan Kuini, } \\
\text { Kolak Pampi/ Kokolek, } \\
\text { Doi Doi, } \\
\text { Du'gok, } \\
\text { Meusakat, }\end{array}$} & $\begin{array}{l}\text { Martabak Aceh, } \\
\text { Leupat Gayo, } \\
\text { Peunajoh Tho, } \\
\text { Putroe Manoe, } \\
\text { Pulot, } \\
\text { Timphan } \\
\text { Wajeb, }\end{array}$ \\
\hline Snack & \multicolumn{4}{|l|}{$\begin{array}{l}\text { Keukarah, } \\
\text { Kuweh Seupet }\end{array}$} \\
\hline Beverage & \multicolumn{2}{|l|}{$\begin{array}{l}\text { Gayo, } \\
\text { Ulee Kareeng Coffee, } \\
\text { Coffee Sanger, }\end{array}$} & \multicolumn{2}{|c|}{$\begin{array}{l}\text { Planer Cucumber ice, } \\
\text { Ice Watermelon, } \\
\text { Papaya Cingcau Ice. }\end{array}$} \\
\hline
\end{tabular}

\section{Result and Discussion}

After the 2004 tsunami, and visit Banda Aceh in 2011 the tourism sector has been growing and growing. It can be proved that the Aceh provincial government has a target of 978000 travel until December 2013 was already reached 928 000. Thus there is the achievement of up to $200-300$ tourists, especially foreign tourists from Malaysia. Foreign tourists in the year 2013 to 2000, has already reached 11,000 showed Banda Aceh already attracted tourists. All communities in the archipelago know Mie Aceh, and Aceh Coffee, local government and the city has been carrying out six (6) festival, and which has a 
target to seven (7) as a national and international events. Today the public had been able to see that it has grown with the culinary diversity, therefore the local government and the city tried to push to improve the quality and quantity to develop nationally and internationally in order to make culinary tourism as a major tourist attraction. This is consistent with exposure Nabani, explained very diverse culinary culture is still need to be improved in efforts to clarify the price standardization, improve attitudes and behavior-oriented and service excellence, quality of taste has not changed. It was the government's effort to cities and regions to achieve synergy in the growth of tourism itself.

Aceh has eight ethnic make Aceh have diverse flavors and is a potential source of culinary tourism has a long history. Therefore they show optimism when the implementation of the Focus Group Discussion (FGD) "Making Manuscript of Potential Culinary Tourism", in the Hotel Oasis on May 27, 2016 together with Cultural Tourism Development Deputy Ministry of Tourism of Republic Indonesia which was attended by approximately 50 people culinary experts from Banda Aceh city. They consist of representatives from provincial, and municipal governments, industry stakeholders, and the cultural culinary going to give birth to new ideas and to the development of culinary tourism untapped.

Finnaly they agreed to declare the FGD the main culinary from Banda Aceh City, which is have value with history, tradition and philosophy, and use local raw material as follows;

Table 0.2 The Main Traditional Culinary of Banda Aceh

\begin{tabular}{|c|c|c|c|}
\hline No & Menu & Description & Photo \\
\hline 1 & $\begin{array}{l}\text { Kuwah } \\
\text { Beulangong }\end{array}$ & $\begin{array}{l}\text { Kuwah Beulangöng, or often referred to as } \\
\text { gulèe sie kamèng (goat curry), is a kind of curry } \\
\text { dishes of Aceh. The main raw material is goat } \\
\text { meat and jackfruit, slices Kapok Banana. } \\
\text { Various spices used are roasted coconut, } \\
\text { coconut flour, cinnamon, red chili peppers, } \\
\text { dried chili, cayenne pepper, garlic, ginger, } \\
\text { turmeric, roasted coriander, nutmeg, and ginger. } \\
\text { Everything is milled and then cooked in a large } \\
\text { pot. How to cook the meat is put in a pot, then } \\
\text { mixed with spices and salt until evenly } \\
\text { distributed. Then add enough water until half } \\
\text { cooked. Furthermore, young jackfruit pieces put } \\
\text { back in, and the water are added until } \\
\text { completely cooked. The menu actually is a } \\
\text { culinary tradition that shows the togetherness of } \\
\text { the Acehnese. Curried Goat's typical Aceh has a } \\
\text { rich flavor, tender meat without smell pungent } \\
\text { of goat. This stew has the taste and aroma of } \\
\text { spices typical of Aceh. Various other foods such } \\
\text { as rice, grilled mutton pieces and chunks of } \\
\text { green chili can be a served to eat curry Aceh. } \\
\text { Besides it, also can be eaten with Cane bread. }\end{array}$ & \\
\hline 2 & Ayam Tangkap & $\begin{array}{l}\text { This cuisine such as fried chicken with herbs } \\
\text { and spices typical of Aceh. Deliciousness full of } \\
\text { flavor made popular in the country Ayam } \\
\text { Tangkap from The Veranda of Mecca. Cooking } \\
\text { process is also unique. Chicken cut into small } \\
\text { pieces, seasoned with onion, garlic, pepper, } \\
\text { nutmeg, salt, and ginger before frying, and when } \\
\text { it is fried for 5-10 minutes also included } \\
\text { simultaneously handfuls of curry leaves; } \\
\text { Temurui, Koja leaves, Pandan leaves and green } \\
\text { chilli. The taste of this spice will seep up into } \\
\text { the chicken. That is the secret delights Ayam } \\
\text { Tangkap. In several place, the menu is dubbed }\end{array}$ & \\
\hline
\end{tabular}




\begin{tabular}{|c|c|c|c|}
\hline & & $\begin{array}{l}\text { with the term due to "The Tsunami Chicken", } \\
\text { this dish is usually served with dishes such } \\
\text { irregularity is dispersed after the tsunami. The } \\
\text { habit of eating chicken arrest have become part } \\
\text { of the culture of the people of Aceh. The menu } \\
\text { is presented with the leaves that cover the } \\
\text { chicken. While still warm, the leaves have a } \\
\text { crunchy texture like chips. The menu usually } \\
\text { served with soy sauce and rice spices warm. } \\
\text { Price per package Rp } 60,000 \text { per. Ordin portion } \\
\text { ordinary for } 4-5 \text { people. }\end{array}$ & \\
\hline 3 & Mie Aceh & $\begin{array}{l}\text { Mie Aceh is ttraditional dishes typical of The } \\
\text { province Veranda of Mecca. This dishes is } \\
\text { famous for its spicy flavor, fresh and tasty } \\
\text { surprisingly easy to make. Thick yellow noodles } \\
\text { with slices of beef, lamb or seafood served in a } \\
\text { kind of soup is savory and spicy curries. The } \\
\text { uniqueness of Aceh noodles are distinctive } \\
\text { flavor Aceh which is a heritage of the Acehnese. } \\
\text { At the time of consuming Mie Aceh, usually } \\
\text { provide a pickle for example crackers, } \\
\text { cucumber, carrot, onion, and so on. Types of } \\
\text { noodles used are yellow noodles thick and } \\
\text { straight, and is usually mixed with various } \\
\text { appendages such as sliced beef, lamb, squid, } \\
\text { crab or shrimp. There are two types of Mie } \\
\text { Aceh, fried noodles and boiled noodles. Aceh } \\
\text { noodle stew with spicy curry sauce most } \\
\text { delicious eaten hot. }\end{array}$ & \\
\hline 4 & Sanger Coffee & $\begin{array}{l}\text { Sanger is a mixture of black coffee, condensed } \\
\text { milk and sugar. Physically, Sanger is similar to } \\
\text { coffee with milk or caffee latte. But make no } \\
\text { mistake, Sanger instead of regular milk coffee. } \\
\text { Not all coffee drinks makers can make Sanger. } \\
\text { Because to make Sanger dose of coffee, } \\
\text { condensed milk and sugar should be fit. After } \\
\text { the coffee brewed with a filter cloth cone shape, } \\
\text { and then coupled with condensed milk plus a } \\
\text { little sugar and whipped until frothy. Although } \\
\text { already mixed with milk, coffee aroma still } \\
\text { dominate. That's what led Sanger instead of } \\
\text { regular milk coffee. It is said that to get Sanger } \\
\text { delights, a mixture of milk and sugar only } \\
\text { slightly. Sanger can be enjoyed hot or cold. For } \\
\text { sipping pleasure of Sanger. Sanger coffee first } \\
\text { appeared in } 1997 \text { in a coffee shop Atalanta, } \\
\text { Ulee Kareng, outskirts of Banda Aceh. Sanger } \\
\text { could serve hot or cold, depending on taste. } \\
\text { Aceh society recognizes two versions of the } \\
\text { history of Sanger. One version of the origin of } \\
\text { the word is mentioned Sanger was "Sange". } \\
\text { This designation to facilitate the designation of } \\
\text { coffee blends, mixed with milk and sugar added. } \\
\text { Another version says, Sanger stems from a } \\
\text { number of students in } 1996 \text { wanted to drink } \\
\text { coffee milk. because of deteriorating economic } \\
\text { conditions at that time, students play the brain } \\
\text { that can still drink coffee mixed with milk. So } \\
\text { was born the idea as "equally understand" } \\
\text { abbreviated to Sanger. Keep students can enjoy } \\
\text { an affordable coffee milk, a number of students } \\
\text { asked coffee maker to make coffee, mix a little } \\
\text { milk and sugar added in order to make sweet. } \\
\text { Some of communities in Aceh makes Aceh } \\
\text { Sanger as a typical drink. In } 2015 \text {, they held } \\
\text { "Sanger Day", and one of the activities is } 9 \\
\text { coffee shop in Aceh provide free hundreds of } \\
\text { glasses of Sanger for loyal customers. }\end{array}$ & 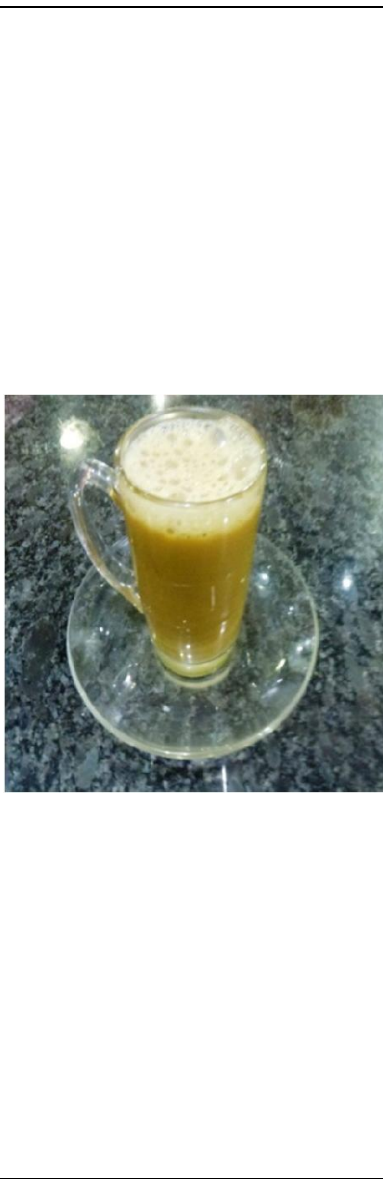 \\
\hline
\end{tabular}




\begin{tabular}{|c|c|c|c|}
\hline 5 & Gule Plik $U$ & $\begin{array}{l}\text { Gule Plik U is a kind of curry from coconut } \\
\text { milk dishes are quite popular in public of Banda } \\
\text { Aceh. The stew is typical east coast of Aceh, } \\
\text { served with rice and fried fish. This menu is } \\
\text { also typically provided in specific event but } \\
\text { often also of everyday dishes people of Banda } \\
\text { Aceh. Various kinds of fresh vegetables are } \\
\text { blended, and cooked with special spices. Plik U } \\
\text { is a coconut that has been fermented. Prices } \\
\text { range from Rp 8,000 per plate. Main raw } \\
\text { material from this menu is "pliek" a kind of pulp } \\
\text { manufacture of coconut oil with the process of } \\
\text { decay and squeeze the oil content. Dregs had } \\
\text { not contain the oil then dried and subsequently } \\
\text { used as the main ingredient manufacture this } \\
\text { menu. In addition to "Plik", leafy vegetables } \\
\text { were added among young jackfruit, papaya fruit, } \\
\text { coconut milk, melinjo leaves, beans, bamboo } \\
\text { shoots kecombrang, melinjo fruit, small shrimp, } \\
\text { and so on. As a complement to eat rice, Kuah } \\
\text { Pliek U also often served with fried fish. }\end{array}$ & \\
\hline 6 & $\begin{array}{l}\text { Gulee Masam } \\
\text { Keueung }\end{array}$ & $\begin{array}{l}\text { Gulee Masam Keueung is one of the typical } \\
\text { dishes Aceh terrace sour and spicy. The cuisine } \\
\text { is only in Aceh but the presentation is different } \\
\text { pad every district in Aceh. Fish that are obtained } \\
\text { when the divided will be the Masam Keueng } \\
\text { and it will be very different from some other } \\
\text { regions. Arguably every area of Aceh has a } \\
\text { distinctive seasoning Masam Keueng. }\end{array}$ & \\
\hline 7 & Sie Reuboh & $\begin{array}{l}\text { Sie Reuboh is cooked meat is beef, mutton or } \\
\text { buffalo meat braised with garlic, cayenne } \\
\text { pepper, salt and vinegar, then covered with lime } \\
\text { juice and aerated during the day and night. After } \\
\text { a marinade seep, flesh cut into pieces and fried } \\
\text { until becoming like shredded. Sie distinctive } \\
\text { taste Reuboh Puteh derived from palm vinegar } \\
\text { alias gampong vinegar made from palm. This } \\
\text { menu vaporize fragrance vinegar are hard and } \\
\text { teasing. Sweet vinegar is spread along the spicy } \\
\text { taste sour mix up to the palate when eaten. } \\
\text { Fragrant palm vinegar is the dominating flavor } \\
\text { of boiled meat, which is hard to miss. This } \\
\text { menu, is a typical food of Aceh Besar district } \\
\text { which was inherited and became mandatory } \\
\text { meal when arriving Ramadan. There is a feature } \\
\text { of the menu is where the mill chili, cayenne, red } \\
\text { and chilli in a rough state so that the seeds will } \\
\text { be sticky on the surface of the meat later. } \\
\text { Enjoyment of this dish depends on the raw } \\
\text { material meat used. Selection of a good beef is } \\
\text { highly recommended, as for the beef used is } \\
\text { usually the meat has inside or outside has. The } \\
\text { more tender the meat so as to facilitate the } \\
\text { process of cooking. Sie reuboh does have its } \\
\text { own character. In addition to it's unique, the } \\
\text { cuisine is also durable, or can be stored for days. } \\
\text { One advantage of this reuboh sie, will not be } \\
\text { stale. When you have a cold, stay heated, still } \\
\text { good to eat anytime. Therefore, when the } \\
\text { residents of Aceh Besar Meugang often make } \\
\text { Sie Reuboh, and can be saved as a menu Iftar or } \\
\text { sahur. This menu has a long history, formerly } \\
\text { used as food for the troops who wanted to go to } \\
\text { war. Because it is durable and not perishable, } \\
\text { food is often also become Peunajoh Prang or } \\
\text { war logistics. Every soldier who participated } \\
\text { while fighting, always equipped with sie reuboh } \\
\text { as a food ingredient. }\end{array}$ & $r=$ \\
\hline
\end{tabular}




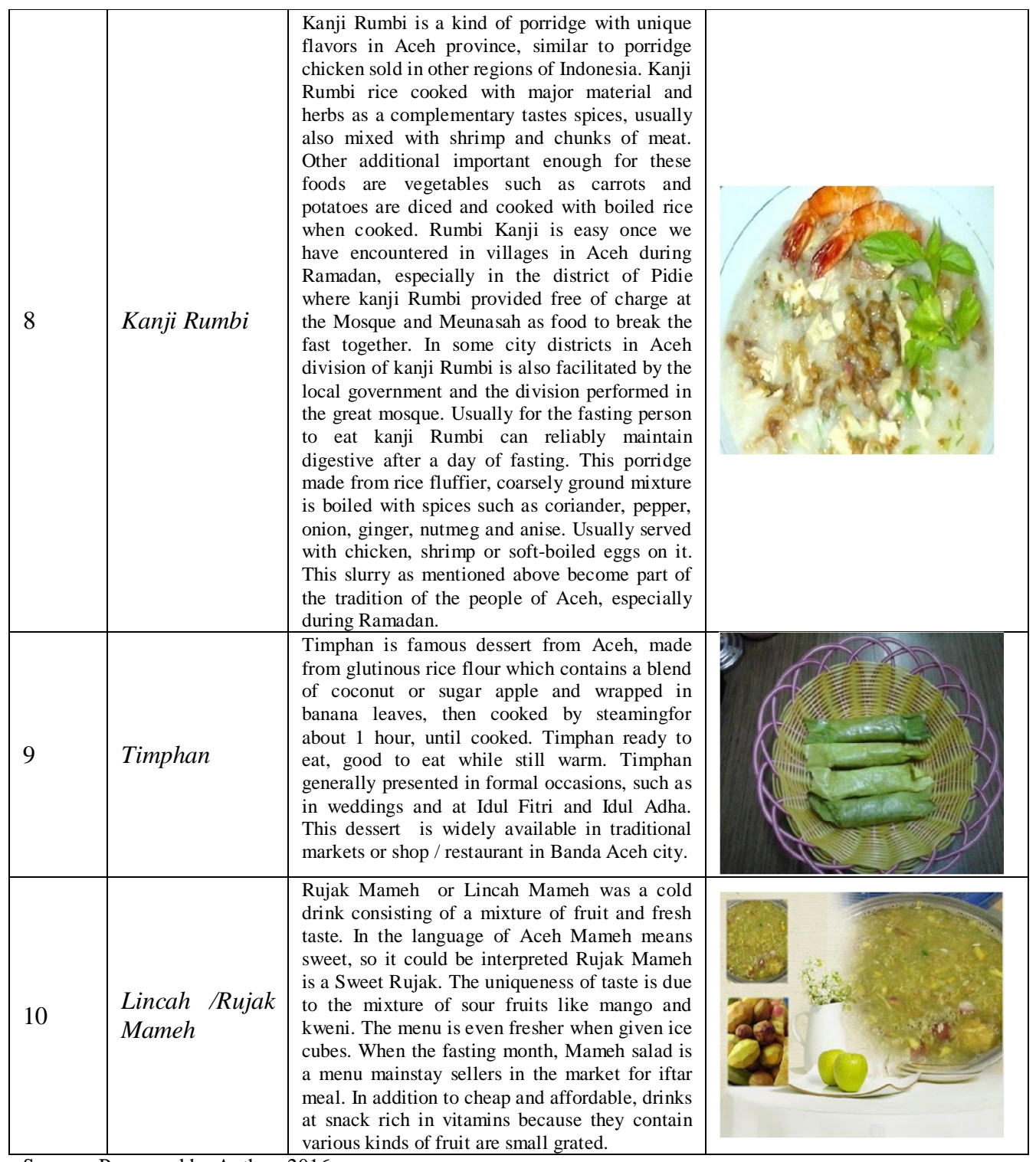

Source : Processed by Author, 2016

\section{CONCLUSSION AND RECOMMENDATION Conclussion}

Culinary development in Aceh related with long story of Aceh Sultanate that form culture and tradition. The culinary tradition that form by tradition as follows:

1) The tradition of coffee, has become part of social and cultural life of Banda Aceh in the presence of dozens of coffee shops that grow in this city.

m) The tradition of welcoming Ramadan like Kanji Rumbi, Takjil Ie Bu Peudah, and Bulukuat Kuah Tuhe.

n) Sie Puteh is thick soupy dishes rich in spices, and has a unique taste and savory. For the people of Pidie and Pidie Jaya, Maulid without Sie Puteh was not yet complete. Each day celebration of indigenous and Meugang, Sie Puteh is always as one dish menu. Culinary is also easily found in other areas in 
Aceh, such as Aceh Besar, and Banda Aceh. In tradition of Idang was brought to Meunasah or Mosque when Maulid, usually also served Sie Puteh menu.

o) Beurat tradition, is one of festivity in the Community of Lamno Aceh Jaya. This feast was held on Ramadan, and takes place at night in the middle of the month of Sha'ban. Tonight the course of this festivity known as Beurat night. This festivity is implemented by all members of a village community, and located in Meunasah led by Teungku. At this feast the whole community comes to Meunasah carrying a Idang (food packages consisting of rice and side dishes, and placed in a large tray). The food is eaten with other community members who were present at the time of Kaurie Beurat.

p) Marriage, urban Acehnese in performing weddings typically serves a diverse menu of food served called as Idang and also as a symbol of a particular food menu, such as Bhoi Cake, Kuweh Seupet.

q) The people of Aceh since the days of empire are already familiar with a variety of menus that have a long endurance to face the natural conditions, and also social and political unfriendly, such as Keumamah, Keukarah, Sie Reuboh.

Determination of ten culinary featured a stakeholder agreements in Aceh is Kuwah Belangong, Ayam Tangkap, Mie Aceh, Kopi Sanger, Timphan, Kuah Pliek U, Gulai Masam Keueung, Sie Reuboh, Kanji Rumbi, and Lincah Mameh.

\section{Recommendation}

Development of culinary tourism in Banda Aceh City has the potential to be exploited, but of course there needs to be a commitment from local governments and municipalities to immediately conduct inventories with documentation also narrative is loaded with social and cultural values that grow along its development. It will be a strength because it is unique in this field.

Procedures with standard system services need to be able to serve with accurate, responsive, secure and have high empathy industry needs to be improved in order to provide excellent service to visitors, especially domestic and foreign tourists.

\section{REFERENCE}

Banda Aceh Tourism. (2016). Warung Kuliner Tradisional di Kota Banda. http://www.bandaacehtourism.com/objek-wisata/kuliner/warung-kulinertradisional-di-kota-banda/\#.Vz6e0fl97IU. Diakses 22 Mei 2016.

Corigliano, A. (2002). The route to quality: Italian gastonomy networks in operations. In A.M. hjalager and G. Richards (eds.), Tourism and Gastronomy, London: Routledge.

David, L., \& Tozser, A. (2009). Destination Management: Necessity And Tasks Of Tourism Destination Management In Hungary. Applied Studies in Agribusiness and Commerce, Vol. 3, No.6, 81-84.

Gunn, C. A., \& Var, T. (1994). Tourism Planning: Basics, Concepts, Cases. New York: McGraw Hill. 
Hall, C. M., \& Mitchell, R. (2001). Wine and Food Tourism. In N. Douglas, N. Douglas \& R. Derrett (Eds.), Special Interest Tourism: Wiley.

Inskeep, E. (1991). Tourism planning: an integrated and sustainable development approach. New York: Van Nostrand Reinhold.

Symons, M. (1999). Gastronomic authenticity and the sense of place. Paper presented at the 9th Australian Tourism and Hospitality Research Conference for Australian University Tourism and Hospitality Education.

Turgarini, Dewi and Abdillah, Fitri. (2016). Laporan Akhir Profil Wisata Kuliner Kota Banda Aceh. Jakarta. Asisten Deputi Pengembangan Wisata Budaya.Kementrian Pariwisata

UNWTO. (2013). UNWTO Tourism Highlight 2010 Edition. New York: UNWTO Publications Department.

Viva. (2015). Kolak Khas Aceh Bulukat Kuah Tuhe. http://www.viva.co.id/ramadhan2015/news/read/ 647875/kolak-khas-aceh-bulukat-kuah-tuhe. Diakses pada 21 Mei 2016.

Wolf, E. (2006). Culinary Tourism: The Hidden Harvest. Dubuque: Kendall/Hunt Publishing.

Wurianto, A.B (2008). Aspek Budaya pada Tradisi Kuliner Tradisional di Kota Malang sebagai Identitas Sosial Budaya (Sebuah Tinjauan Folklore). UMM. Malang. 